\title{
Immunodetection and quantification of insulin-like antigens in sprouts: development of an efficient functional food
}

\author{
Manju Pathak ${ }^{1}$ and Danik M. Martirosyan ${ }^{2,3}$ \\ ${ }^{1}$ Amity Institute of Biotechnology, Amity University, Sector-125, Noida, India \\ ${ }^{2}$ Functional Food Center, Richardson TX, 75080, USA; ${ }^{3}$ Department of Internal Medicine, UT \\ Southwestern Medical Center, Dallas TX, USA
}

\section{Corresponding Authors:}

1. Manju Pathak, PhD, Professor, Amity Institute of Biotechnology, Amity University, Sector-125, Noida, India

2. Danik M. Martirosyan, PhD, Assistant Professor, Department of Internal Medicine, UT Southwestern Medical Center, 5323 Harry Hines Blvd, Dallas TX, 75390, USA, Phone: 469441-8272

Submission date: October 17, 2011; Acceptance date: November 29, 2011; Publication date: November 30, 2011

Running title: Sprouts can be a good source of insulin

\section{Abstract:}

Background: Hormone Insulin is a drug used for the treatment of type 1 and type 2 Diabetes Mellitus. Insulin used in this experiment is derived from bovine and pork pancreas, as well as through recombinant technology. Patients with diabetes mellitus face an inability to utilize glucose from blood due to either less secretion of insulin, or the inability of the insulin to act; As a result of this glucose levels in the blood rise. The prevention and treatment of type 2 Diabetes Mellitus one is world's major public health issues. Natural alternatives have a big role to play in this field. This study aims at discovering functional foods rich in Insulin like proteins. Here we are reporting Insulin-like proteins synthesizing during the embryo development stage of Glycine max: soybean, Vigna radiata: moong and Vigna unguiculata: cowpea seeds. Hence, germination transforms these seeds containing human insulin like proteins.

Methods: In our investigation we have provided protein extraction with Enzyme-linked immunosorbent assay (ELISA). The plant materials weighing $1 \mathrm{~g}$ were crushed in mortar and pestle, and the protein from the plant materials was extracted with $20 \mathrm{ml}$ of $0.05 \mathrm{M}$ sodium phosphate buffer ( $\mathrm{pH}$ 7.6). The suspensions were centrifuged at $6000 \mathrm{rpm}$ for $15 \mathrm{~min}$, and the clear supernatants were subjected to Enzyme linked immunosorbent assay (ELISA) for the 
detection of insulin-like proteins. We have used USDA nutritional data sources for the analysis of new products.

Results: Our results demonstrate that Insulin is not expressed in dry mature dormant seeds, but is expressed only during the embryo development stage. Dry mature dormant seeds and the seeds germinated for 24 hours, 48 hours, 72 hours, and 96 hours of Glycine max, Vigna radiata and Vigna unguiculata, were investigated for expression of insulin through immunodetection using anti-insulin antibodies. Dry dormant seeds of all the three seeds showed zero expression at 450 $\mathrm{nm}$ for insulin, while significant presence of insulin showing positive immuno-reactivity towards anti-insulin antibodies were observed at 24 hours, 48 hours, 72 hours, and at 96 hours of germination.

Conclusion: The study is suggesting that insulin-like proteins are synthesized only during the process of embryo development, the sprouts of such legumes, particularly soybeans, can be a good source of insulin.

Key words: Germination, insulin, seed embryo development, sprouts.

\section{INTRODUCTION:}

Peptides are a major class of signal molecules in animals that regulate a wide variety of physiological and developmental processes. It was once thought that plants have not evolved signaling systems that use a peptide as a signal.

The first peptide hormone, insulin, was discovered in 1922 [1]. The role of insulin and insulin-like growth factors in animals has been well established to be associated with glucose metabolism, cell growth, and survival, respectively. Though there are many arguments that reject the presence of the peptide hormone insulin in plants, there is strong evidence, since the discovery of insulin that suggests the presence of insulin-like proteins in plants with similar characteristics as those of animal insulin [2].

Seed germination is a central process that is the key to plant development and plant survival. This important event involves metabolism reactivation, translation of stored mRNAs, rapid growth, and cell division. Insulin has been shown to promote seed germination of monocot and dicot plants and accelerate the post-germination development of fat-storing seeds [3]. Also, insulin regulates selective translation in the maize embryonic axis through activation of corresponding maize S6 kinase (ZmS6 kinase) [4]A $4 \mathrm{kDa}$ peptide, leginsulin, was found to be present in radicles of the germinated seeds of soybean, moong bean, and different legume species, which can bind to soybean basic $7 \mathrm{~S}$ globulin $(\mathrm{Bg})$, which showed similarity to animal hormone receptors and compete with insulin for binding to $\mathrm{Bg}$ [5]. This $4 \mathrm{kDa}$ peptide stimulates protein kinase activity of $\mathrm{Bg}$ and regulates the growth and cell proliferation of plant callus [6]. A protein with amino acid sequence homology to bovine insulin was shown to be present in the developing fruits of cowpeas [7]. This evidence suggests the possible role of insulin-like proteins in growth, cell proliferation, and sugar transport, during seed germination. This study was carried 
out to investigate the effect of seed germination on synthesis of insulin in seeds of Glycine max (soybean), Vigna radiata (moong bean), and Vigna unguiculata (cow pea).

It was found that insulin-like proteins were not detected in the raw seeds, where as significant levels of insulin were detected after the germination of the seeds. This report is another source of evidence for the presence of insulin-like proteins in legumes, with emphasis on its role during the phase of seed embryo development. The report also suggests that the expression of insulin is highly regulated. We reported earlier on the high blood sugar regulating efficacy of Glycine max sprouts [8].

\section{METHODS AND MATERIALS:}

Plant material: Dry dormant seeds of Glycine max (soybean), Vigna radiata (mung bean), and Vigna unguiculata (cow pea), were washed thoroughly with water and soaked for 8 hours. After 8 hours, the water was drained, and the seeds were kept in wet cotton clothes and allowed to germinate. The clothes were always kept wet through the sprinkling water at frequent intervals. Germinated seeds were collected at $24,48,72$, and 96 hours, and dried at $50^{\circ} \mathrm{C}$ in an incubator.

Antibodies: Anti-pig insulin antibodies produced in guinea pigs, with $100 \%$ cross reactivity to human and bovine insulin (Sigma Aldrich, USA), and anti-guinea pig IgG produced in goat, conjugated to horse radish peroxidase (HRP) (Sigma Aldrich, USA), were used.

Protein extraction: The plant materials weighing $1 \mathrm{~g}$ were crushed in mortar and pestle, and the protein from the plant materials was extracted with $20 \mathrm{ml}$ of $0.05 \mathrm{M}$ sodium phosphate buffer $(\mathrm{pH}$ 7.6)[10, 11]. The suspensions were centrifuged at $6000 \mathrm{rpm}$ for $15 \mathrm{~min}$, and the clear supernatants were subjected to Enzyme linked immunosorbent assay (ELISA) for the detection of insulin-like proteins.

Enzyme-linked immunosorbent assay (ELISA): The 10 $\mu 1$ of protein samples prepared from dry dormant seeds and 24 hour, 48 hour, 72 hour, and 96 hour germinated seeds, were diluted with $990 \mu 1$ carbonate/bicarbonate buffer $(0.05 \mathrm{M}, \mathrm{pH} 9.6)$ [12]. $100 \mu 1$ of these solutions were coated on the wells of microtitre plates (96 well Maxisorp type, Nunc, Roskilde, Denmark), and incubated at $4{ }^{\circ} \mathrm{C}$ overnight. The wells were washed with Phosphate buffered saline, containing $0.05 \%$ Tween 20 (PBS-T), for $1 \mathrm{~h} .300 \mu \mathrm{l}$ of blocking solution (2\% non-fat dry milk in PBS-T) was added to each of the wells, and incubated for 1 hour at room temperature. The wells were washed with PBS-T and $50 \mu \mathrm{l}$ of anti-insulin $\mathrm{IgG}$, raised in guinea pig (1:5000) solution, prepared with a blocking buffer, was added to each of the wells and incubated for 1 hour at room temperature. The wells were again washed with PBS-T and 50 $\mu 1$ of anti- guinea pig IgG raised in goat - HRP conjugate (1:3000) solution prepared with a blocking buffer was added to each of the wells, and incubated for 1 hour at room temperature [9, 13]. The wells were washed with PBS-T and $100 \mu 1$ of TMB (3, 3', 5, 5' tetramethyl benzidine) / H2O2 (hydrogen peroxide) (Bangalore GeNei, India), which is the substrate of HRP, was added to each of the wells and incubated at room temperature for 15-30 min, untill sufficient blue color develops. The reaction was stopped 
by adding $100 \mu \mathrm{l}$ of $2 \mathrm{M}$ sulfuric acid, and the absorbance was read at 450nm [13] using the ELISA plate reader (ELx800, BioTek, U.S).

Human insulin of recombinant DNA origin (INSUGEN-R Regular soluble short acting insulin, BIOCON) was used as the standard. (The composition of each $\mathrm{ml}$ is Human insulin IP 40 IU (International Unit), m-Cresol USP $0.25 \%$ w/v, water for injection IP q.s). Concentration of insulin was made to $10 \mu \mathrm{g} / 100 \mu \mathrm{l}$ and serially dilution to $1 \mathrm{x} 10-8 \mu \mathrm{g} / 100 \mu \mathrm{l}$ with a carbonate / bicarbonate buffer. Controls for each of the samples employing the secondary antibody without the addition of primary antibodies were performed.

ELISA Experimental design and data analysis: Six experiments of ELISA were carried out. ELISA 1, 2 and 3 were performed with the freshly precipitated protein solution from the dried germinated seeds, and ELISA 4, 5 and 6 were performed with the protein samples which were stored for 48 hours in the refrigerator. Each ELISA was designed in a way to accommodate the samples of raw seeds, and seeds germinated for 24 hours, 48 hours, 72 hours, and 96 hours, of all the three beans under the study. All samples of the individual seeds were tested in triplicate. These were technical replicates; no biological replicates were used here. Three wells were taken as controls for each of the germinated seed samples, and one as the control for each raw seed sample. The average value was taken for further analysis. The net absorbance for each of the samples was calculated by deducting the absorbance of the controls from that of the observed absorbance of the test samples. The level (concentration) of insulin was represented in terms of the net absorbance values at 450nm. The concentrations of insulin in the test samples were determined from the standard graph. The concentrations of insulin in $1 \mathrm{~g}$ of the dried seeds were also calculated. The standard graph and the determination of the concentrations of insulin in the test samples were done using the software GraphPad Prism 5.

Nutritional Analyses: Nutritional analysis was made using the information provided by USDA Nutritional Database. All ingredients were purchased from local grocery stores. Ingredients for the salads included: kidney beans, beets, carrots, vegetable oil (soybean oil), canola oil, onions, potatoes, sauerkraut, sprouted soybeans, parsley, salt, and black peppers.

\section{RESULTS:}

Fresh protein precipitates, and 48-hour-old protein precipitates of dry dormant seeds (raw seeds) and germinated for 24 hours, 48 hours, 72 hours and 96 hours of G.max (Glycine max), V.radiata (Vigna radiata) and V.unguiculata (Vigna unguiculata) were subjected to six ELISA tests. The presence of insulin was analyzed with anti-insulin antibodies. Insulin-like proteins were not detected in any of the raw seeds, whereas detectable amounts of insulin-like proteins, that showed immuno-reactivity towards the anti-insulin antibodies, were present in all of the germinated seeds, as evident in Table 1. The absorbance in 48-hour-old protein samples was found to be little lesser than that of the freshly prepared samples. The net absorbance in three test samples of six ELISA tests of raw seeds of all the seeds under investigation was observed to be zero (Table 1). We report the presence of insulin-like proteins that are immuno-reactive to antiinsulin antibodies in all the germinated seeds under study, whereas these were absent in the raw seeds. 
Table 1. Levels of insulin-like proteins in raw and germinated seeds of G.Max, V.radiata, V.unguiculata as measured by ELISA and represented as Absorbance at $450 \mathrm{~nm}$ after rounding off to two decimal places.

\begin{tabular}{|c|c|c|c|c|c|c|c|c|c|c|c|}
\hline \multirow[b]{2}{*}{ Test sample } & \multicolumn{9}{|c|}{$\begin{array}{l}\text { Net Absorbance at } 450 \mathrm{~nm} \text { (observed absorbance minus the control } \\
\text { absorbance) }\end{array}$} & \multirow[b]{2}{*}{$\begin{array}{l}\% \\
\text { Absor- } \\
\text { bance }\end{array}$} & \multirow[b]{2}{*}{$\begin{array}{l}\text { \% Difference } \\
\text { in } \\
\text { Absorbance }^{+}\end{array}$} \\
\hline & $\begin{array}{l}\text { Elisa } \\
\mathbf{1}\end{array}$ & $\begin{array}{l}\text { Elisa } \\
2\end{array}$ & $\begin{array}{l}\text { Elisa } \\
\mathbf{3}\end{array}$ & $\begin{array}{l}\text { Average } \\
\text { of Elisa } \\
1,2 \& 3 \text {. }\end{array}$ & $\begin{array}{l}\text { Elisa } \\
4\end{array}$ & $\begin{array}{l}\text { Elisa } \\
5\end{array}$ & $\begin{array}{l}\text { Elisa } \\
6\end{array}$ & $\begin{array}{l}\text { Average } \\
\text { of Elisa } \\
4,5 \& 6\end{array}$ & $\begin{array}{l}\text { Averages } \\
\text { of } 6 \\
\text { Elisa's }\end{array}$ & & \\
\hline \multicolumn{12}{|l|}{ G.max } \\
\hline Raw & 0.00 & 0.00 & 0.00 & 0.00 & 0.00 & 0.00 & 0.00 & 0.00 & 0.00 & 0 & 0 \\
\hline $24 \mathrm{~h} \mathrm{G}^{\ddagger}$ & 0.19 & 0.19 & 0.19 & 0.19 & 0.16 & 0.15 & 0.15 & 0.15 & 0.17 & 17 & +17 \\
\hline $48 \mathrm{~h} \mathrm{G}^{\ddagger}$ & 0.16 & 0.31 & 0.31 & 0.26 & 0.19 & 0.19 & 0.19 & 0.19 & 0.23 & 23 & +6 \\
\hline $72 \mathrm{~h} \mathrm{G}^{\ddagger}$ & 0.49 & 0.54 & 0.54 & 0.52 & 0.21 & 0.37 & 0.37 & 0.32 & 0.42 & 42 & +19 \\
\hline $96 \mathrm{~h} \mathrm{G}^{*}$ & 0.20 & 0.20 & 0.20 & 0.20 & 0.13 & 0.13 & 0.12 & 0.13 & 0.16 & 16 & -26 \\
\hline \multicolumn{12}{|l|}{ V. radiata } \\
\hline Raw & 0.00 & 0.00 & 0.00 & 0.00 & 0.00 & 0.00 & 0.00 & 0.00 & 0.00 & 0 & 0 \\
\hline $24 \mathrm{~h} \mathrm{G}^{+}$ & 0.07 & 0.07 & 0.07 & 0.07 & 0.08 & 0.07 & 0.07 & 0.07 & 0.07 & 7 & +7 \\
\hline $48 \mathrm{~h} \mathrm{G}^{\ddagger}$ & 0.15 & 0.15 & 0.15 & 0.15 & 0.10 & 0.10 & 0.11 & 0.10 & 0.13 & 13 & +6 \\
\hline $72 \mathrm{~h} \mathrm{G}^{*}$ & 0.07 & 0.07 & 0.07 & 0.07 & 0.08 & 0.08 & 0.07 & 0.08 & 0.07 & 7 & -6 \\
\hline $96 \mathrm{~h} \mathrm{G}^{*}$ & 0.17 & 0.17 & 0.17 & 0.17 & 0.10 & 0.09 & 0.10 & 0.10 & 0.13 & 13 & +6 \\
\hline \multicolumn{12}{|l|}{ V.unguiculata } \\
\hline Raw & 0.00 & 0.00 & 0.00 & 0.00 & 0.00 & 0.00 & 0.00 & 0.00 & 0.00 & 0 & 0 \\
\hline $24 \mathrm{~h} \mathrm{G}^{\ddagger}$ & 0.08 & 0.08 & 0.08 & 0.08 & 0.06 & 0.06 & 0.06 & 0.06 & 0.07 & 7 & +7 \\
\hline $48 \mathrm{~h} \mathrm{G}^{\ddagger}$ & 0.12 & 0.12 & 0.12 & 0.12 & 0.13 & 0.12 & 0.13 & 0.13 & 0.12 & 12 & +5 \\
\hline $72 \mathrm{~h} \mathrm{G}^{\ddagger}$ & 0.06 & 0.06 & 0.06 & 0.06 & 0.08 & 0.08 & 0.07 & 0.08 & 0.07 & 7 & -5 \\
\hline $96 \mathrm{~h} \mathrm{G}^{\ddagger}$ & 0.27 & 0.27 & 0.27 & 0.27 & 0.16 & 0.15 & 0.15 & 0.15 & 0.21 & 21 & +14 \\
\hline \multicolumn{12}{|l|}{$\begin{array}{l}* * \text { Standard } \\
\mu \mathrm{g} \text { insulin / } \\
100 \mu \mathrm{l} \\
\text { solution }\end{array}$} \\
\hline $1 \times 10^{1}$ & 1.93 & 1.87 & 1.76 & 1.85 & 1.45 & 1.44 & 1.50 & 1.46 & 1.66 & & \\
\hline $1 \times 10^{0}$ & 1.61 & 1.39 & 1.22 & 1.41 & 1.61 & 1.37 & 1.12 & 1.37 & 1.39 & & \\
\hline $1 \times 10^{-1}$ & 1.43 & 1.12 & 1.12 & 1.22 & 1.17 & 1.16 & 0.91 & 1.08 & 1.15 & & \\
\hline $1 \times 10^{-2}$ & 1.24 & 1.24 & 1.24 & 1.24 & 1.34 & 1.12 & 1.01 & 1.16 & 1.20 & & \\
\hline $1 \times 10^{-3}$ & 0.64 & 0.64 & 0.63 & 0.64 & 0.93 & 0.89 & 1.06 & 0.96 & 0.80 & & \\
\hline $1 \times 10^{-4}$ & 0.52 & 0.64 & 0.64 & 0.60 & 0.87 & 0.56 & 0.56 & 0.66 & 0.63 & & \\
\hline $1 \times 10^{-5}$ & 0.31 & 0.31 & 0.33 & 0.32 & 0.42 & 0.45 & 0.48 & 0.45 & 0.39 & & \\
\hline $1 \times 10^{-6}$ & 0.21 & 0.21 & 0.21 & 0.21 & 0.33 & 0.35 & 0.37 & 0.35 & 0.28 & & \\
\hline $1 \times 10^{-7}$ & 0.11 & 0.11 & 0.11 & 0.11 & 0.22 & 0.33 & 0.30 & 0.28 & 0.20 & & \\
\hline $1 \times 10^{-8}$ & 0.08 & 0.08 & 0.08 & 0.08 & 0.11 & 0.11 & 0.11 & 0.11 & 0.10 & & \\
\hline
\end{tabular}

* Percentage absorbance is expressed as a fraction of $100 ;{ }^{\dagger}$ ' + ' Sign indicates the increase in absorbance and '-' sign indicated the decrease in absorbance; ${ }^{*}$ ' $G$ ' indicates germinated; **Human insulin of rDNA origin

Levels of insulin in germinating seeds: The net absorbance values were rounded off to two decimal places, and the trend in the changes of insulin levels in the germinated seeds for various time periods was analyzed. Net expression of insulin varied with the various intervals of time. The variation pattern was similar in all of the experiments of ELISA for respective beans. In G.max, the dry dormant seeds expressed a $0 \%$ absorbance at $450 \mathrm{~nm}$ while an increase of $17 \%$ insulin was observed at 24 hours of germination, followed by a further increase of $6 \%$ and $19 \%$ at 48 hours and 72 hours of germination; then there was a drop by $26 \%$ at 96 hours of 
germination. It is clearly observed that insulin is expressed only during germination. In V.radiata, the dry dormant seeds expressed $0 \%$ absorbance at $450 \mathrm{~nm}$ while an increase of $7 \%$ insulin was observed at 24 hours of germination, followed by an increase of $6 \%$ at 48 hours. There was then a decrease of $6 \%$ insulin at 72 hours, and again an increase of $6 \%$ at 96 hours of germination. In V.unguiculata, the dry dormant seeds expressed $0 \%$ absorbance at $450 \mathrm{~nm}$, while an increase of $7 \%$ insulin was observed at 24 hours of germination, followed by an increase of $5 \%$ at 48 hours. There was then a drop of insulin level at $5 \%$ at 72 hours, and again an increase of $14 \%$ at 96 hours. In G.max, the levels of insulin were observed to increase with an increasing period of germination with the maximum at 72 hours, and then there was a decrease while in V.radiata and V.unguiculata. Afterward, insulin levels increased till 48 hours, and then a fell in the level of insulin, which was observed at 72 hours, followed by an increase at 96 hours. Maximum levels of insulin were observed at 48 hours and 96 hours of germination in V.radiata and V.unguiculata, respectively (Table 1).

\section{Trend in the levels of insulin in germinating seeds}

The level of insulin in Glycine max smoothly increased during embryo development until 72 hours of germination, and then dropped. So, the pattern in Glycine max is uniform. This was not the case with Vigna radiata and Vigna unguiculata (Figure 1).

(a)

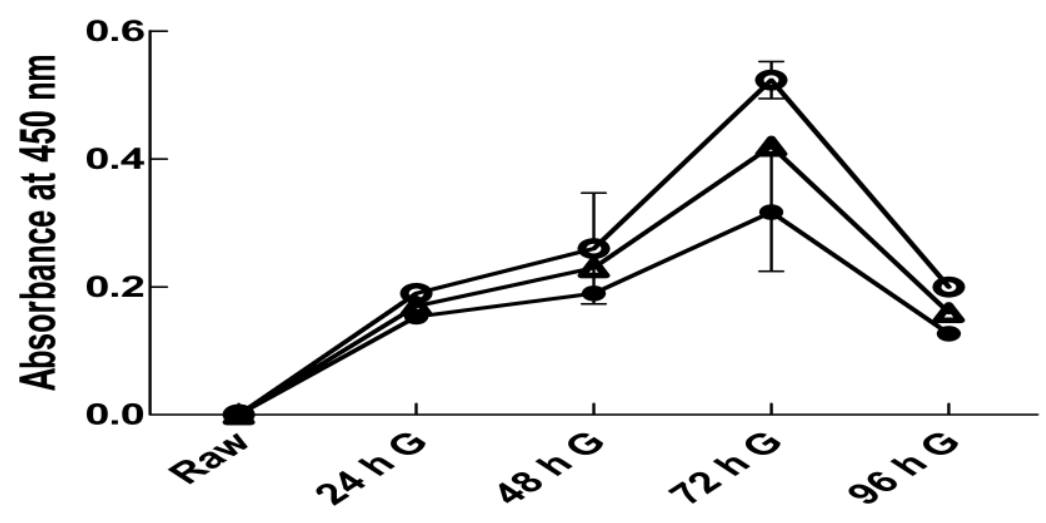

(b) 


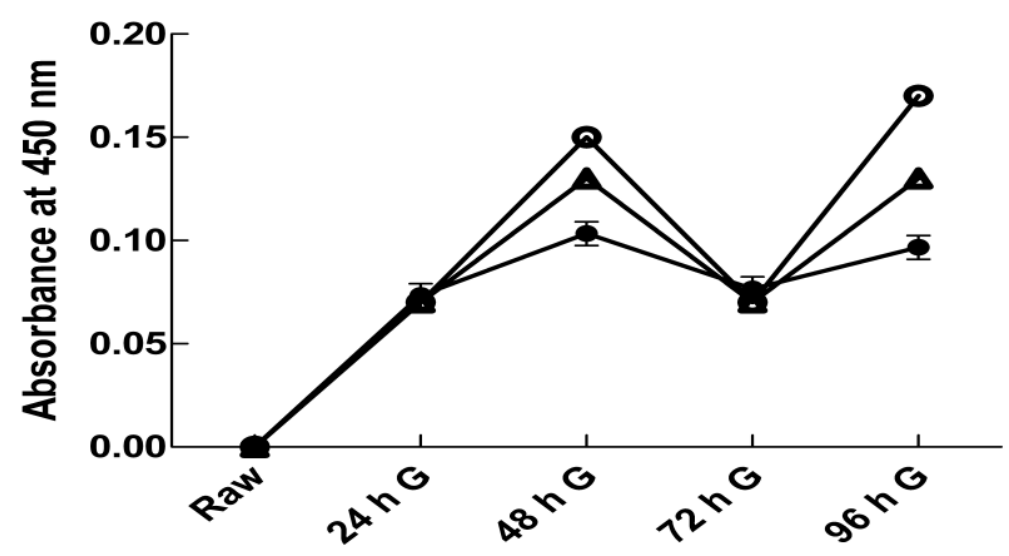

(c)

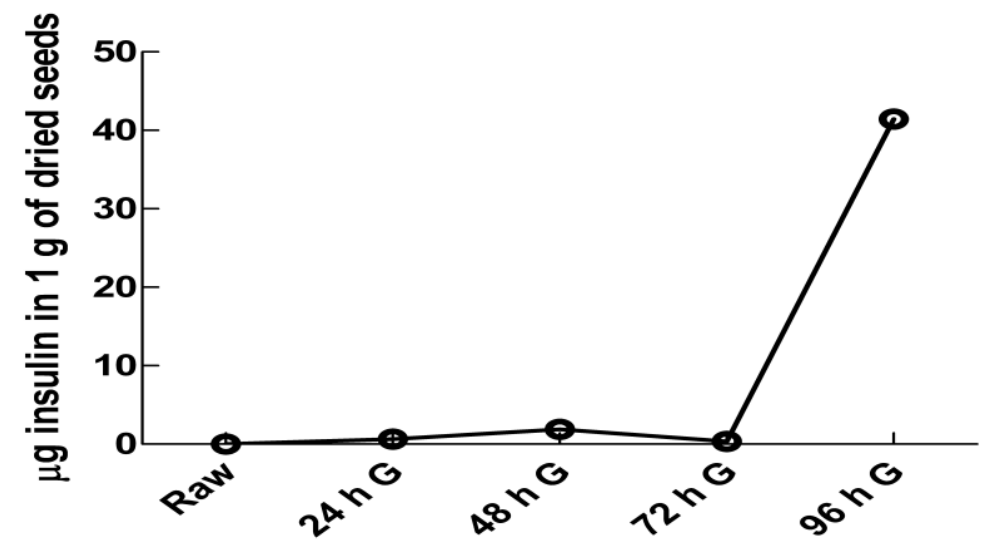

Figure 1. Levels of insulin-like protens in raw and germinated seeds of (a) Glycine max, (b) Vigna radiata and (c) Vigna unguiculata.

The concentrations of insulin-like proteins are represented as the Absorbance at 450nm. ELISA 1,2, and 3 corresponds to the freshly prepared samples and ELISA 4,5, and 6 corresponds to 48hour-old samples. 'G' stands for germinated seeds. In these two beans, a zigzag pattern of insulin expression was observed. In them the exact same levels of insulin expression at 24 hours of germination is observed. It is further increasing at approximately equal levels at 48 hours of germination, and again dropping approximately equally at 72 hours and then again going up at 96 hours of germination.

Table 2: Concentration of insulin present in $100 \mu \mathrm{l}$ of the protein samples and in $1 \mathrm{~g}$ of dried seeds

\begin{tabular}{|c|c|c|c|}
\hline Test Sample & $\begin{array}{l}\text { Amount of Insulin } \\
\left(\mathbf{x 1 0}^{-10} \mu \mathrm{g}\right) \text { present in } \\
100 \mu \mathrm{l} \text { of freshly prepared } \\
\text { protein sample }\end{array}$ & $\begin{array}{l}\text { Amount of Insulin } \\
\left(\times 10^{-10} \mu \mathrm{g}\right) \text { present in } \\
100 \mu \mathrm{l} \text { of } 48 \mathrm{hr} \text { old protein } \\
\text { sample }\end{array}$ & $\begin{array}{l}\text { Insulin levels }\left(\mathrm{x}^{-3} \mathrm{o}^{-3} \mathrm{~g}\right) \\
\text { per g of seeds }(\mathrm{dried}) \\
\text { calculated from the data } \\
\text { observed for freshly } \\
\text { prepared protein samples }\end{array}$ \\
\hline $\operatorname{Raw}($ G.max $)$ & 0.00 & 0.00 & 0.00 \\
\hline 24 h germinated & 4644.00 & 156.08 & 9.29 \\
\hline $48 \mathrm{~h}$ germinated & 17418.00 & 452.68 & 34.84 \\
\hline
\end{tabular}




\begin{tabular}{|l|l|l|l|}
\hline 72 h germinated & 1000000.00 & 6285.90 & 2000.00 \\
\hline 96 h germinated & 5684.90 & 84.83 & 11.37 \\
\hline Raw V. radiata $)$ & 0.00 & 0.00 & 0.00 \\
\hline 24 h germinated & 242.34 & 8.15 & 0.48 \\
\hline 48 h germinated & 1956.00 & 29.64 & 3.91 \\
\hline 72 h germinated & 242.34 & 12.97 & 0.48 \\
\hline 96 h germinated & 3050.30 & 29.64 & 6.10 \\
\hline Raw V. unguiculata $)$ & 0.00 & 0.00 & 0.00 \\
\hline 24 h germinated & 325.63 & 4.91 & 0.65 \\
\hline 48 h germinated & 955.17 & 84.83 & 1.91 \\
\hline 72 h germinated & 178.11 & 12.97 & 0.36 \\
\hline 96 h germinated & 20709.00 & 156.08 & 41.42 \\
\hline
\end{tabular}

The observation of the study clearly indicates that the presence of insulin like proteins in the legume seeds is characteristic of the germination process. Insulin present in protein concentrate, as well as Insulin present in $1 \mathrm{gm}$ of the sprout was calculated Table-2, Figure-2).

\section{Glycine max}

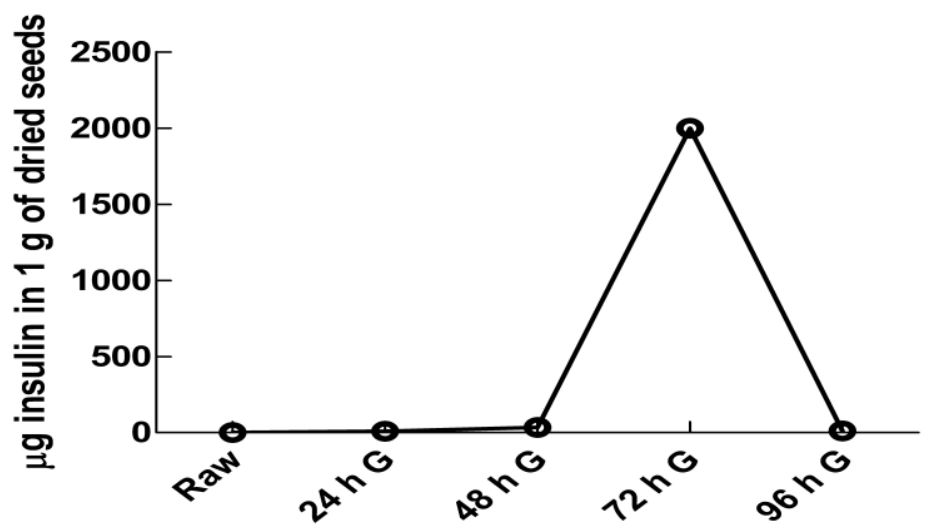

Vigna radiata

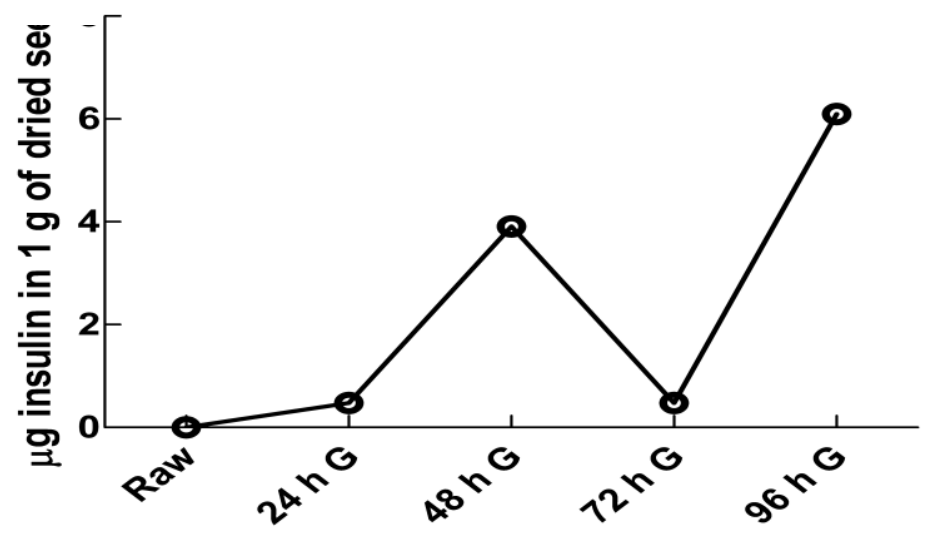

(c)

Vigna unguiculata 


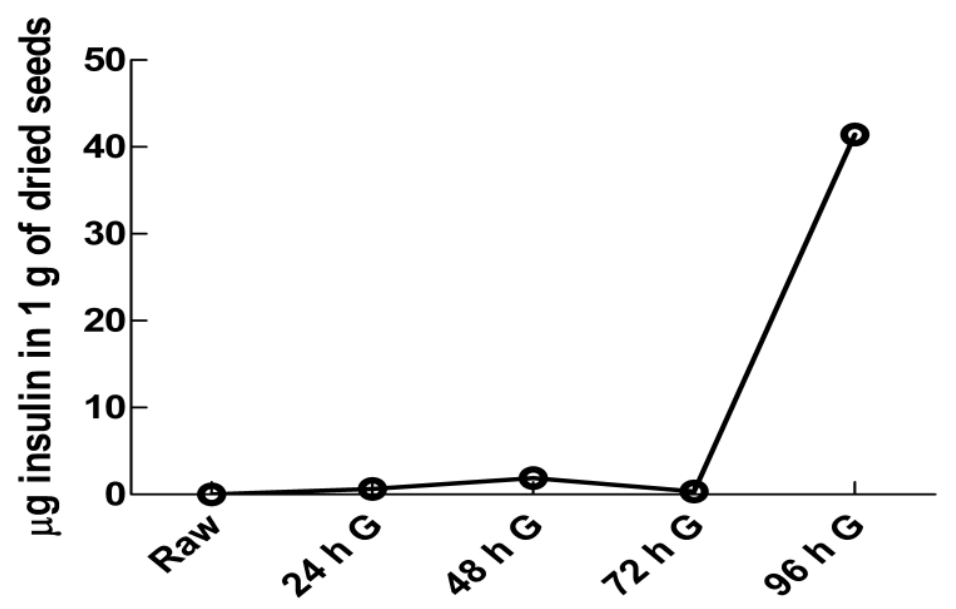

Figure 2. Insulin levels per gram of dried seeds of (a) G.max, (b) V.radiata and (c) V.unguiculata. ELISA data observed in freshly prepared protein samples were used.

This investigation shows that soybean sprout is a source of insulin. Therefore, development of new functional food products with soybean sprouts would be beneficial for people who suffer from type 2 diabetes, or who are in the pre-diabetic stage. On the base of recent functional product formulation VGT.CO (Figure 3, we created a new formulation (Figure 4 and Figure 5). of VGT.CO.Spr.SB50 which had substitution of 50\% of kidney be by sprouted soybeans (Figure 4) and in the formulation of VGT.CO.Spr.SB100 we have substituted $100 \%$ of kidney beans by sprouted soybean (Figure 5).

Figure 3. Nutrition Facts of VGT.CO (Salad with kidney bean) 


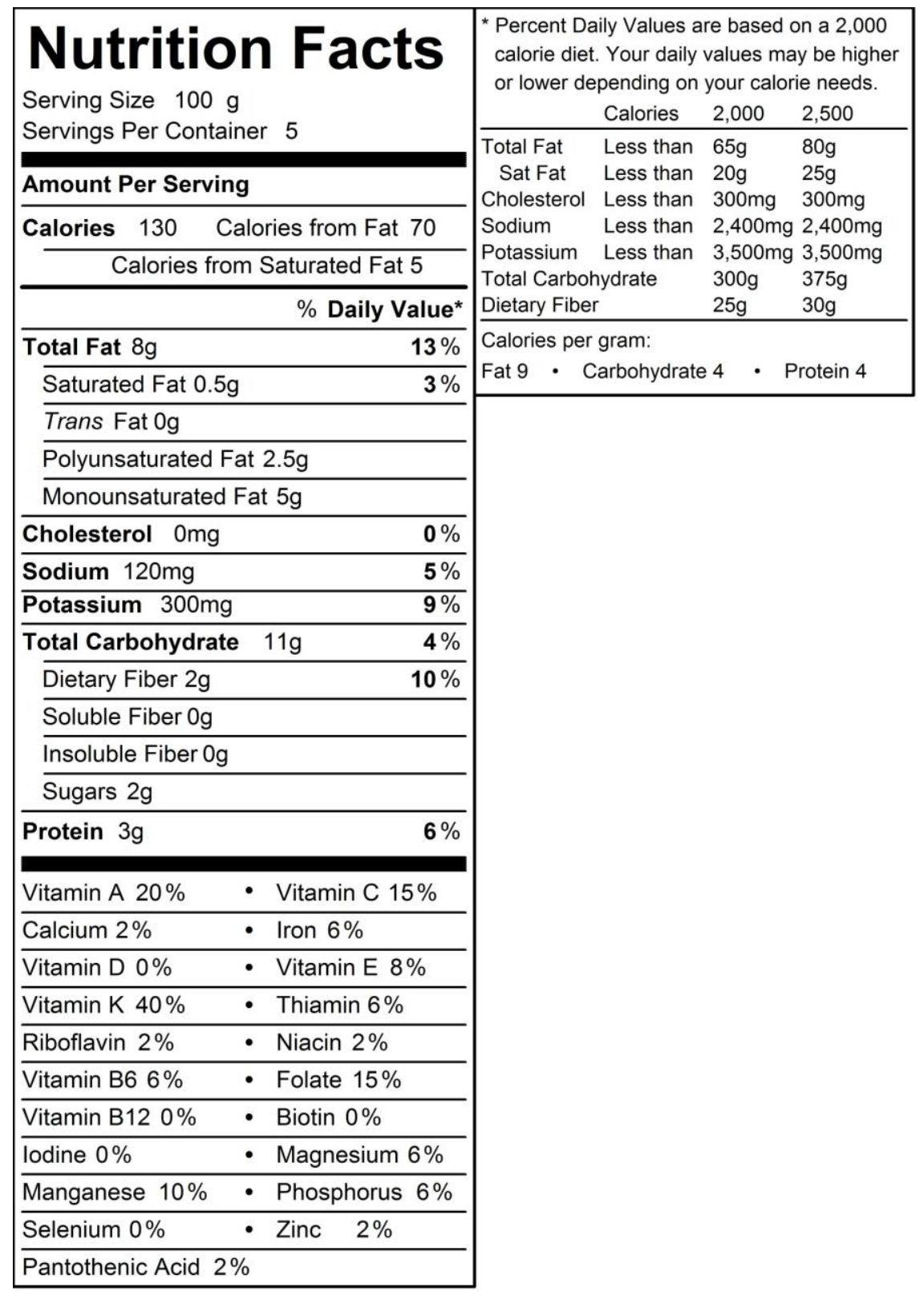

Ingredients: kidney beans, beets, carrots, vegetable oil (soybean oil), canola oil, onions, potato, salt, sauerkraut, parsley, and black peppers.

Computerized analysis shows that VGT.CO is cholesterol free, low in saturated Fat (3\%), a source of folate (15\%), vitamin C (15\%), vitamin A $(20 \%)$ and a good source of vitamin K $(40 \%)$. It is an excellent source of omega-3 (0.690 g per serving). The ratio of omega 3 to Omega 6 was $1: 2.16$.

Nutritional composition of new product with 50\% sprouted soybean provided in the Figure 4 .

Figure 4. VGT.CO.Spr.SB50 Nutrition facts 


\begin{tabular}{|c|c|c|c|}
\hline \multirow{3}{*}{$\begin{array}{l}\text { Nutrition Facts } \\
\text { Serving Size } 100 \mathrm{~g} \\
\text { Servings Per Container } 5\end{array}$} & \multirow{2}{*}{\multicolumn{3}{|c|}{$\begin{array}{l}\text { * Percent Daily Values are based on a } 2,000 \\
\text { calorie diet. Your daily values may be higher } \\
\text { or lower depending on your calorie needs. } \\
\text { Calories } \quad 2,000 \quad 2,500\end{array}$}} \\
\hline & & & \\
\hline & \multirow{5}{*}{\begin{tabular}{|ll} 
Total Fat & Less than \\
Sat Fat & Less than \\
Cholesterol & Less than \\
Sodium & Less than \\
Potassium & Less than \\
Total Carbohydrate \\
Dietary Fiber
\end{tabular}} & \multirow{5}{*}{$\begin{array}{l}65 \mathrm{~g} \\
20 \mathrm{~g} \\
300 \mathrm{mg} \\
2,400 \mathrm{mg} \\
3,500 \mathrm{mg} \\
300 \mathrm{~g} \\
25 \mathrm{~g} \\
\end{array}$} & \multirow{5}{*}{$\begin{array}{l}80 \mathrm{~g} \\
25 \mathrm{~g} \\
300 \mathrm{mg} \\
2,400 \mathrm{mg} \\
3,500 \mathrm{mg} \\
375 \mathrm{~g} \\
30 \mathrm{~g} \\
\end{array}$} \\
\hline Amount Per Serving & & & \\
\hline \multirow{2}{*}{$\frac{\text { Calories } 130 \quad \text { Calories from Fat } 70}{\text { Calories from Saturated Fat } 5}$} & & & \\
\hline & & & \\
\hline \% Daily Value* & & & \\
\hline \multirow{2}{*}{$\begin{array}{lr}\text { Total Fat } 8 \mathrm{~g} & 13 \% \\
\text { Saturated Fat } 0.5 \mathrm{~g} & 3 \%\end{array}$} & \multirow{2}{*}{\multicolumn{3}{|c|}{$\begin{array}{l}\text { Calories per gram: } \\
\text { Fat } 9 \quad \cdot \text { Carbohydrate } 4 \quad \cdot \text { Protein } 4\end{array}$}} \\
\hline & & & \\
\hline Trans Fat Og & & & \\
\hline Polyunsaturated Fat $2.5 \mathrm{~g}$ & & & \\
\hline Monounsaturated Fat $5 \mathrm{~g}$ & & & \\
\hline & & & \\
\hline $\begin{array}{ll}\text { Sodium 120mg } & \mathbf{5 \%} \\
\end{array}$ & & & \\
\hline \multirow{2}{*}{$\begin{array}{lll}\text { Potassium } 300 \mathrm{mg} & 9 \% \\
\text { Total Carbohydrate } & 11 \mathrm{~g} & 4 \%\end{array}$} & & & \\
\hline & & & \\
\hline $\begin{array}{lr}\text { Dietary Fiber } 2 \mathrm{~g} & \mathbf{9 \%} \\
\end{array}$ & & & \\
\hline Soluble Fiber 0g & & & \\
\hline Insoluble Fiber Og & & & \\
\hline Sugars $2 \mathrm{~g}$ & & & \\
\hline $\begin{array}{ll}\text { Protein } 3 g & 7 \%\end{array}$ & & & \\
\hline - Vitamin C $15 \%$ & & & \\
\hline Calcium $2 \%$ & & & \\
\hline - Vitamin E $8 \%$ & & & \\
\hline Vitamin K $40 \%$ & & & \\
\hline Riboflavin $2 \%$ & & & \\
\hline Vitamin B6 6\% & & & \\
\hline Vitamin B12 0\% & & & \\
\hline - Magnesium 6\% & & & \\
\hline - Phosphorus 6\% & & & \\
\hline Selenium 0\% & & & \\
\hline Pantothenic Acid $2 \%$ & & & \\
\hline
\end{tabular}

Ingredients: kidney beans, beets, carrots, vegetable oil (soybean oil), canola oil, onions, potato, salt, sauerkraut, sprouted soybeans, parsley, and black peppers.

This food is cholesterol free, low in saturated fat (3\%), a source of folate (15\%), vitamin C $(15 \%)$, vitamin A $(20 \%)$ and a good source of vitamin K (40\%). It is an excellent source of omega-3 (0.690 g per serving). The ratio of omega 3 to omega 6 is $(1: 2.63)$.

Nutritional composition of new product with 100\% sprouted soybean provided in the Figure 5.

Figure 5. VGT.CO.Spr.SB.100 Nutrition facts 


\begin{tabular}{|c|c|c|c|}
\hline \multirow{3}{*}{$\begin{array}{l}\text { Nutrition FaCtS } \\
\text { Serving Size } 100 \mathrm{~g} \\
\text { Servings Per Container } 5\end{array}$} & \multicolumn{3}{|c|}{$\begin{array}{l}\text { * Percent Daily Values are based on a 2,000 } \\
\text { calorie diet. Your daily values may be higher } \\
\text { or lower depending on your calorie needs. }\end{array}$} \\
\hline & Calories & 2,000 & 2,500 \\
\hline & \multirow{5}{*}{\begin{tabular}{|ll} 
Total Fat & Less than \\
Sat Fat & Less than \\
Cholesterol & Less than \\
Sodium & Less than \\
Potassium & Less than \\
Total Carbohydrate \\
Dietary Fiber
\end{tabular}} & \multirow{5}{*}{\multicolumn{2}{|c|}{$\begin{array}{ll}65 \mathrm{~g} & 80 \mathrm{~g} \\
20 \mathrm{~g} & 25 \mathrm{~g} \\
300 \mathrm{mg} & 300 \mathrm{mg} \\
2,400 \mathrm{mg} & 2,400 \mathrm{mg} \\
3,500 \mathrm{mg} & 3,500 \mathrm{mg} \\
300 \mathrm{~g} & 375 \mathrm{~g} \\
25 \mathrm{~g} & 30 \mathrm{~g} \\
\end{array}$}} \\
\hline Amount Per Serving & & & \\
\hline \multirow{2}{*}{$\begin{array}{c}\text { Calories } 130 \quad \text { Calories from Fat } 80 \\
\text { Calories from Saturated Fat } 5 \\
\end{array}$} & & & \\
\hline & & & \\
\hline$\%$ Daily Value* & & & \\
\hline Total Fat $9 \mathrm{~g}$ & \multirow{2}{*}{\multicolumn{3}{|c|}{ 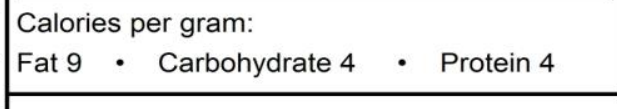 }} \\
\hline Saturated Fat $1 \mathrm{~g}$ & & & \\
\hline Trans Fat $0 \mathrm{~g}$ & & & \\
\hline Polyunsaturated Fat $3 g$ & & & \\
\hline Monounsaturated Fat $5 \mathrm{~g}$ & & & \\
\hline Cholesterol Omg & & & \\
\hline Sodium 95mg & & & \\
\hline Potassium $310 \mathrm{mg}$ & & & \\
\hline $\begin{array}{lll}\text { Total Carbohydrate } & 10 \mathrm{~g} & \mathbf{3} \% \\
\end{array}$ & & & \\
\hline Dietary Fiber $2 \mathrm{~g} \quad \mathbf{7 \%}$ & & & \\
\hline Soluble Fiber $0 \mathrm{~g}$ & & & \\
\hline Insoluble Fiber 0g & & & \\
\hline Sugars $2 \mathrm{~g}$ & & & \\
\hline $\begin{array}{ll}\text { Protein } 4 \mathrm{~g} & 7 \%\end{array}$ & & & \\
\hline Vitamin A $20 \% \quad$ Vitamin C $20 \%$ & & & \\
\hline Calcium 2\% $\quad$ • Iron 6\% & & & \\
\hline Vitamin D 0\% $\quad$ • Vitamin E 6\% & & & \\
\hline Vitamin K $35 \% \quad$ • Thiamin $6 \%$ & & & \\
\hline $\begin{array}{ll}\text { Riboflavin } 2 \% & \text { Niacin } 4 \% \\
\end{array}$ & & & \\
\hline Vitamin B6 8\% $\quad$ • Folate $15 \%$ & & & \\
\hline Vitamin B12 0\% $\quad \cdot$ Biotin 0\% & & & \\
\hline - Magnesium $8 \%$ & & & \\
\hline Manganese $15 \% \quad$ • Phosphorus $6 \%$ & & & \\
\hline $\begin{array}{ll}\text { Selenium } 0 \% & \text { • Zinc } \quad 2 \% \\
\end{array}$ & & & \\
\hline Pantothenic Acid $4 \%$ & & & \\
\hline
\end{tabular}

Ingredients: beets, carrots, vegetable oil (soybean oil), canola oil, onions, potato, salt, sauerkraut, sprouted soybeans, parsley, and black peppers.

This food is cholesterol free, low in saturated fat (4\%), a source of manganese (15\%), folate (15\%), vitamin A (20\%), vitamin C (20\%) and a good source of vitamin K (35\%). It is an excellent source of omega-3 (0.690 g per serving). The ratio of omega 3 to omega 6 is 1:3.1

Fat composition in VGT.CO.Spr.SB100 provided on the Table 3.

Table 3. Fat Composition in VGT.CO.Spr.SB100 


\begin{tabular}{|l|l|}
\hline Total Fat & 9.027 gr \\
\hline Saturated Fat & 0.769 gr \\
\hline Monounsaturated Fat & 5.102 gr \\
\hline Polyunsaturated Fat & 2.939 gr \\
\hline Omega-3 Fat & $\mathbf{0 . 6 9 0}$ gr \\
\hline Omega-6 Fat & $\mathbf{2 . 1 4 7}$ gr \\
\hline Trans Fat & 0.030 gr \\
\hline Cholesterol & $0.000 \mathrm{mg}$ \\
\hline Other Fats & $8.061 \mathrm{mg}$ \\
\hline
\end{tabular}

Vitamin Composition in VGT.CO.Spr.SB 100 provided on the Table 4.

Table 4. Vitamin Composition in VGT.CO.Spr.SB100

\begin{tabular}{|c|l|l|}
\hline Nutrient & Amount & Units \\
\hline & & \\
\hline Vitamins: & & \\
\hline Vitamin A & 44.912 & $\mu \mathrm{g} \mathrm{RAE}$ \\
\hline Retinol & 0.000 & $\mu \mathrm{g} \mathrm{RAE}$ \\
\hline Carotene & 44.716 & $\mu \mathrm{g} \mathrm{RAE}$ \\
\hline Beta-Carotene & 36.962 & $\mu \mathrm{g} \mathrm{RAE}$ \\
\hline Alpha-Carotene & 7.395 & $\mu \mathrm{g}$ RAE \\
\hline Beta-Cryptoxan... & 0.360 & $\mu \mathrm{g} \mathrm{RAE}$ \\
\hline Lycopene & 0.000 & $\mu \mathrm{g}$ RAE \\
\hline Lutein+Zeaxan... & 4.612 & $\mu \mathrm{g} \mathrm{RAE}$ \\
\hline Thiamin (B1) & 0.103 & $\mathrm{mg}$ \\
\hline Riboflavin (B2) & 0.048 & $\mathrm{mg}$ \\
\hline Niacin (B3) & 0.619 & $\mathrm{mg}$ \\
\hline Vitamin B6 & 0.142 & $\mathrm{mg}$ \\
\hline Vitamin B12 & 0.000 & $\mu \mathrm{g}$ \\
\hline Betaine & 22.054 & $\mathrm{mg}$ \\
\hline Biotin & 0.000 & $\mu \mathrm{g}$ \\
\hline Choline & 6.290 & $\mathrm{mg}$ \\
\hline Total Folate & 62.032 & $\mu \mathrm{g}$ \\
\hline Food Folate & 62.032 & $\mu \mathrm{g}$ \\
\hline Folic Acid & 0.000 & $\mu \mathrm{g}$ \\
\hline Inositol & 0.000 & $\mathrm{mg}$ \\
\hline Pantothenic & 0.322 & $\mathrm{mg}$ \\
\hline Vitamin C & 11.727 & $\mathrm{mg}$ \\
\hline Vitamin D & 0.000 & $\mu \mathrm{g}$ \\
\hline & & \\
\hline
\end{tabular}




\begin{tabular}{|l|l|l|}
\hline Total Vitamin E & 1.394 & $\mathrm{mg}$ \\
\hline d-Alpha-Tocoph... & 0.000 & $\mathrm{mg}$ \\
\hline dl-Alpha-Tocoph... & 0.000 & $\mathrm{mg}$ \\
\hline Beta-Tocopherol & 0.002 & $\mathrm{mg}$ \\
\hline Gamma-Tocoph... & 2.073 & $\mathrm{mg}$ \\
\hline Delta-Tocopherol & 0.075 & $\mathrm{mg}$ \\
\hline Alpha-Tocotrienol & 0.000 & $\mathrm{mg}$ \\
\hline Beta-Tocotrienol & 0.000 & $\mathrm{mg}$ \\
\hline Gamma-Tocotrie... & 0.000 & $\mathrm{mg}$ \\
\hline Delta-Tocotrienol & 0.000 & $\mathrm{mg}$ \\
\hline Vitamin K & 29.732 & $\mu \mathrm{g}$ \\
\hline Other Vitamins & 0.000 & $\mathrm{mg}$ \\
\hline
\end{tabular}

Sterols composition in VGT.CO.Spr.SB100 provided on the Table 5.

Table 5. Sterols Composition in VGT.CO.Spr.SB100

\begin{tabular}{|l|c|}
\hline Sterols: & \\
\hline Betasterol & $31.211 \mathrm{mg}$ \\
\hline Campesterol & $18.213 \mathrm{mg}$ \\
\hline Cholesterol & $0.000 \mathrm{mg}$ \\
\hline Phytosterol & $8.06 \mathrm{mg}$ \\
\hline Stigmasterol & $0.227 \mathrm{mg}$ \\
\hline
\end{tabular}

\section{DISCUSSION:}

The changes in levels of insulin with regards to changes in the germination period indicate that the expression of these proteins is strongly regulated during germination (Table 1). Metabolism commences in the seeds as soon as their cells are hydrated. Respiration and protein synthesis starts after imbibition, using components conserved in the dry seed. This is followed by synthesis of RNA and DNA repair and synthesis. The final event is the expansion of the cells of the radical, which precedes cell division and mobilization of cell reserves. In soybean, PI3K synthesis has been reported in 72 hours old seedlings [9], which can be correlated with the maximum levels of insulin in 72 hour germinated seeds of soybean observed in our study. This is a phase of cell division and elongation of radicals that can be associated with insulin-activated signaling. Insulin activated signaling is suggested to be required in the protein synthesis and in cell proliferation. Also, it might play a role in sugar metabolism and transport during germination. So, insulin synthesis can be said to be highly regulated in the process of germination, which is reflected in the observations of our study in which the levels of insulin are varying with various germination periods according to the requirement of these proteins for the various physiological processes that take place during germination. 


\section{Expression of insulin only in germinating seeds}

It is very clear from the observations obtained from six ELISA experiments that there is absolutely no insulin expression at the dormancy phase of the three leguminous seeds under investigation. The insulin is expressing only when embryo development occurs. The expression of insulin during germination is in a very defined pattern. Intermediate kinases of insulin signaling pathway like identification of phosphatidyinositol-3-kinase (PI3K) in soybeans during nodule organogenesis that is associated with membrane proliferation[10] and is the target of Rapamycin kinase (ZmTOR)[17] and S6 ribosomal protein kinase (ZmS6)[11,12] in maize during germination suggests the induction of insulin signal transduction during germination. Seed germination is a critical process in plant growth and development, during which the quiescent embryonic cells shift into a metabolically active state in which complex biochemical and physiological changes occur. The absence of proteins in raw seeds with positive immunoreactivity to anti-insulin antibodies and the presence of such proteins in the seeds after various periods of germination would suggest that insulin-like proteins are expressed only during seed germination, and appears to be particularly associated with this process. Expression of these proteins during germination, which involves metabolism reactivation, translation of stored mRNAs followed by transcription and rapid growth, and cell division, strongly indicates that insulin-like proteins have an association with some of these processes. Arabidopsis thaliana SHAGGY-like kinases (AtSK), which are the homologues of the mammalian Glycogen synthase kinase (GSK-3), were found in tissues during gametophyte and embryo development [12]. These kinases play an important role in cell growth and differentiation and protein synthesis in mammals.

Comparison of three formulations, (Figures 3,4,5) show that VGT.CO.Spr.SB.100 product with $100 \%$ of soybean sprouts alongwith base formulstion provided the best yield of Vitamin C, ( $20 \%$ of daily recommended value), and Manganese, (15\% of daily recommended value). It was found to be a very good source of Vitamin $\mathrm{K}$, as well as omega 3 fatty acid. But, the content of omega 6 is more in formulation of VGT.CO.Spr.SB.100, and the ratio of omega 3 to omega 6 was increased. So, for better ratio of omega 3 to omega 6 product VGT.CO.Spr.SB.50 looks more attractive. Data provided on the Table 5 shows that VGT.CO.Spr.SB100 is cholesterol free. The sterol content of VGT.CO.Spr.SB.100 was $31.211 \mathrm{mg}$ for betasterol and $18.213 \mathrm{mg}$ campesterol which are known to improve plasma cholesterol levels via regular dietary intake [13]. Thus the nutritional composition of the developed formulations emphasizes its immense health benefits. The beneficial effect involves improved bone health [14] due to the presence of Vitamin $\mathrm{K}$ and manganese, reduced blood plasma sugars due to its insulin-like activity and most important effect in improving cardiovascular health) due to the presence of excellent amount of omega 3 fatty acid [15] as well as ratio of omega 3 to omega 6 fatty acid and plant sterols.

Future directions: We have to find out the levels of insulin-like proteins in germinated seeds of soybean: (a) Glycine max, (b) Vigna radiata and (c) Vigna unguiculata untilgarmination process is stopped, to see the pick of insulin-like proteins synthesis. 


\section{CONCLUSIONS:}

1. The present study provides valuable insight for exploring the possibility of sprouts as an alternate source of insulin, and for the development of functional foods for treating diabetes.

2. The development of two new products VGT.CO.Spr.SB.50 and VGT.CO.Spr.SB.100 are cholesterol free, and very low in Saturated Fat. They are also a good source of Vitamin A and Vitamin $\mathrm{C}$, a very good source of Vitamin $\mathrm{K}$, and an excellent source of Omega-3.

Acknowledgements: Financial and administrative help was provided by VIT University, Vellore, India, for the investigation of insulin-like antigens in sprouts. All nutritional investigations have been provided at Functional Food Center in Dallas, TX.

Author's contribution: M. P. hypothesized the theory tested in the study, and contributed to the experimental data analysis and manuscript preparation. D.M. provided nutritional analysis of functional products, and contributed to the manuscript preparation and discussion of results. All of the authors have read and approved the final manuscript.

Competing Interests: The authors did not have any conflicts of interest related to the research.

\section{REFERENCES:}

1. Banting, F.G., Best, C.H., Collip, J.B., Campbell, W.R., Fletcher, A.A. (1922) Pancreatic extracts in the treatment of diabetes mellitus. Preliminary report. Can. Med. Assoc.J., 12, 141-146.

2. Xavier-Filho, J., Oliveira, A.E.A., Belarmindo da Silva, L., Azevedo, C.R., Venancio, T.M., Machado, O.L.T., Oliva, M.L., Fernandes, K.V.S., Xavier-Neto, J. (2003) Plant insulin or glucokinin: a conflicting issue. Braz. J. Plant Physiol., 15, 67-78.

3. Goodman, D.B.P., Davis, W.L. (1993) Insulin accelerates the postgerminative development of several fat-storing seeds. Biochem. Biophys. Res. Commun. 190, 440-446.

4. Flores, C.G., Aguilar, R., De la Cruz, H.R., Albores, M., de Jimenez, E.S. (2001) A maize insulin-like growth factor signals to a transduction pathway that regulates protein synthesis in maize. Biochem. J. 358, 95-100.

5. Watanabe, Y., Barbashov, S.F., Komatsu, S., Hemmings, A.M., Miyagi, M., Tsunasawa, S., Hirano, H. (1994) A peptide that stimulates phosphorylation of the plant insulin-binding protein - Isolation, primary structure and cDNA cloning. Eur. J. Biochem. 224, 167-172.

6. Yamazaki, T., Takaoka, M., Katoh, E., Hanada, K., Sakita, M., Sakata, K., Nishiuchi, Y., Hirano, H. (2003) A possible physiological function and the tertiary structure of a 4- kDa peptide in legumes. Eur. J. Biochem. 270, 1269-1276.

7. Venancio, T.M., Oliveira, A.EA., Silva, L.B., Machado, O.L.T., Fernandes, K.V.S., XavierFilho, J. (2003) A protein with amino acid sequence homology to bovine insulin is present in the legume Vigna unguiculata (cowpea) Braz J Med Biol Res 36, 1167-1173.

8. Pathak, M. (2005) Soaked and germinated soybean seeds for blood sugar control A preliminary study. Natural Product Radiance, 4, 405-409 
9. Hong Z, Verma DPS (1994) A phosphatidylinositol 3-kinase is induced during soybean nodule organogenesis and is associated with membrane proliferation. Proc Nati Acad Sci USA 91, 9617-9621.

10. Moreno LTA, De la Cruz RH, Martnez-Castilla LP, et al. (2007) Distinctive expression and functional regulation of the maize (Zea mays L.) TOR kinase ortholog, Mol BioSyst 3, 794802.

11. Cruz RH, Aguilar R, De Jimenez SE (2004) Functional characterization of a maize ribosomal S6 protein kinase (ZmS6K), a plant ortholog of metazoan p70(S6K). Biochemistry 43, 533539.

12. Tavares R, Vidal J, Van Lammeren A, Kreis M (2002) AtSK $\theta$, a plant homologue of SGG/GSK-3 marks developing tissues in Arabidopsis thaliana. Plant Molecular Biology 50, 261-271.

13. Weststrate JA, Meijer GW (1998) Plant sterol-enriched margarines and reduction of plasma total- and LDL-cholesterol concentrations in normocholesterolaemic and mildly hypercholesterolaemic subjects. Eur J Clin Nutr. 52(5):334-43.

14. Gabay O, Sanchez C, Salvat C, Chevy F, Breton M, Nourissat G, Wolf C, Jacques C, Berenbaum F. 2010 Stigmasterol: a phytosterol with potential anti-osteoarthritic properties. Osteoarthritis Cartilage, Jan;18(1):106-16.

15. Simopoulos AP. (2004) Omega-3 fatty acids and antioxidants in edible wild plants. Biol Res.37(2):263-77. 